\title{
Evaluation Of Planning And Implementation Occupational Safety And Health In Hospital Embung Fatimah Batam In 2021
}

\author{
Noni Rokaya Pasaribu ${ }^{1}$, Ermi Girsang ${ }^{2 *}$, Sri Lestari Ramadhani Nasution ${ }^{3}$, \\ Chrismis Novalinda Ginting ${ }^{4}$ \\ ${ }^{1,2,3,4}$ Program Study Master Of Publich Health, School Of Medical, \\ Universitas Prima Indonesia, North Sumatera, Indonesa \\ ${ }^{*}$ Corresponding author: \\ Email: ermigirsang@unprimdn.ac.id
}

\begin{abstract}
.
Hospital occupational health programs have not been fully implemented in hospitals such as evaluation of the work environment, documentation of special and periodic health checks, the risk of occupational diseases (PAK). This type of research is qualitative with 10 informants selected purposively. on the input component: HR K3, the budget, and safety facilities provided are still lacking. In the process component: Risk management, hospital safety and security efforts, occupational health services, and B3 management are good. There are not enough fire prevention and control facilities. Infrastructure management is good with water sources, backup electricity, and periodic maintenance. Management of medical equipment and disaster preparedness is good. In the output component: Supervision is carried out by internal hospitals cases of work accidents are still found, and there is still a shortage of human resources, budget, and $\mathrm{K} 3$ facilities. It is recommended to the management of the hospital to add human resources in the field of work safety according to standards.
\end{abstract}

Keywords : Hospital, Helath Program, Evaliuation

\section{INTRODUCTION}

The hospital service industry has a variety of complicated labor issues and is at risk of experiencing illness and accidents caused by work according to the type of work that is their duty, so hospitals are required to apply Hospital Occupational Health and Safety (K3RS) efforts. The phenomenon that occurs today is often found that the planning and implementation of K3RS has not been carried out optimally based on the specified standards, so that human resources in hospitals encounter occupational safety and health problems (Purba, Girsang, \& Malay, 2018).An implementation of occupational safety and health in hospitals (K3RS) really needs serious attention. Occupational safety and health in hospitals does not only pay attention to hospital users such as patients seeking treatment, hospital visitors, but also the participation of health workers who provide services and non-medical personnel so that they do not experience accidents and occupational diseases (Wati, Ramon, Husin, \& Elianto, 2018). International Labor Organization(ILO) as the world workers' organization states that more than 2.78 million workers die worldwide every year due to accidents while carrying out work and $86.3 \%$ of occupational diseases.which results in death. Meanwhile, work accidents that result in fatalities are around 13.7\% (ILO, 2018). According to the National Safety Council (NSC) report, work accidents for workers in hospitals are $41 \%$ higher than workers in other industrial sectors. Cases that often occur in hospital workers include scratches/cuts, back pain, sprains, needle stick injury (NSI), infectious diseases, burns, and others (Sarastuti, 2016).

Several cases were reported by hospital workers and received compensation, namely cases of sprains / sprains, strains (52\%); crushed skin, bruises (11\%); cuts, tears, needle sticks $(10.8 \%)$; fracture $(5.6 \%)$; internal wounds (2.1\%); burns (2\%); scratched, scuffed (1.9\%); infection (1.3\%); skin infections (1.2\%); and others (12.4\%) (Kemenkes RI, 2017). The United States health service report quoted by the Indonesian Ministry of Health stated that around 5000 health workers were infected with Hepatitis B-47 and were HIV positive and around $600,000-1,000,000$ health workers had experienced needle stick injuries ( $>60 \%$ of cases were not reported) (Ministry of Health RI, 2017) . Reports of work accidents in Israeli hospitals, the 
prevalence of back injury in nurses is the highest (16.8\%), in Australia as many as $87 \%$ of nurses have experienced low back pain and in the United States the prevalence of musculoskeletal injuries is 4.62/100 health workers per year.The Corona Virus Disease (Covid-19) pandemic has prompted the World Health Organization (WHO) to call on governments and health care leaders to address the ongoing threat to the health and safety of healthcare workers and patients in hospitals. Soaring reports of cases of infection, disease, and attacks among health workers dealing with Covid-19. Health workers represent $<3 \%$ of the population in all confirmed COVID-19 countries and $<2 \%$ occur in low- and middle-income countries. Around 14\% of Covid-19 cases reported to WHO are health workers and in some countries with incomplete PPE availability, the proportion can reach $35 \%$. However, data availability and quality are limited, and it is not possible to confirm whether the health worker is infected at work or not. Thousands of health workers who have been confirmed to have COVID-19 have died (WHO, 2020).Deaths of health workers, especially doctors and nurses in Indonesia have continued to increase since the Covid-19 pandemic was reported in March 2020.

Data in August 2020 showed that as many as 105 health workers died (IDI, 2020). Work accident cases occurred in hospitals as many as 560 cases or about $42 \%$ of the total number of cases in workers (Arikhman, 2020).Potential hazards related to occupational health and safety in hospitals such as diseases caused by infectious agents in hospital workers, other potential hazards are work accidents related to electrical installations, radiation, ergonomics, anesthetic gases, hazardous chemicals, and psychosocial disorders (Widihartono \& Gizela, 2019).For the sake of creating work safety guarantees for workers in hospitals, professional strategic services and permanent work procedures are needed, not only depending on the existing regulations and the finances provided, but many elements that must be involved, including planning for organizational implementation in safety. and occupational health in hospitals. The success of an organization can be measured by looking at the extent to which the organization can achieve its goals. The implementation of occupational safety and health at home can be assessed from the effectiveness of the K3 organization in the hospital (Apriliawati \& Ekawati, 2017).

Research conducted by Wati et al., (2018) at the Muko-Muko Hospital that K3RS planning has been going well from risk identification problems to work safety risk management.Fuan's research at the Putri Hijau Hospital in Medan found that the implementation of occupational health and safety in hospitals was still lacking, such as a limited budget which resulted in the less than optimal duties of the Hospital Head and staff in implementing K3RS standards, incomplete K3RS facilities and infrastructure and the unavailability of human resources. Competent K3RS, the duties and functions of K3RS personnel work double so that it is not optimal (Fuan, 2014).Hospital Embung Fatimah Batam Regional is a hospital owned by the Batam City government. The preliminary survey conducted by researchers at the Embung Fatimah Regional General Hospital Batam showed that the number of work accidents at the Embung Fatimah Batam Regional General Hospital in 2019 was recorded as 5 cases, consisting of 4 cases of needle sticks, and 1 case of being hit by an incinerator chimney. Cases of needle sticks occurred in the ED (ED), pathology and anatomy laboratory (PA), ER PK laboratory, and oral surgery polyclinic, while cases of chimney stabbing occurred in infectious building construction. The actions given were the administration of hepatitis $\mathrm{B}$ vaccine and the administration of follow-up vaccines for cases of needle sticks, while those who fell on the chimney were treated in the ER and had to re-control.

\section{LITERATURE REVIEW.}

\subsection{Evaluation}

The word evaluation comes from English, namely 'evaluation' which means 'assessment or assessment'. Thoha (2017) states that evaluation is a planned activity to find out the state of an object using instruments and the results are compared with benchmarks to obtain conclusions.Evaluation is a process to provide information about the extent to which a certain activity has been achieved, how the achievement differs from a certain standard to find out whether there is a difference between the two, and how the benefits that have been carried out have been carried out when compared to the expected expectations. obtained. 
Evaluation allows the implementer of a program to know the actual results achieved. An objective, rational and based on the criteria that have been previously set in the plan will be known whether the results achieved exceed the targets and standards that have been determined, the results achieved are just as expected, or less than what is determined (Umar, 2017). Meanwhile, according to Arikunto (2018).Based on the opinion above, it can be concluded that the definition of evaluation can be interpreted as an evaluation object that shows a stage of assessment, where the results are described in the form of information to determine the state of an object which is then used to determine the right alternative in making a decision.

Evaluation is carried out to achieve a goal in accordance with the object of the evaluation. According to Wirawan (2018) written in his book there are several evaluation objectives, namely:

a. Measuring the impact of the program on the community.

b. Assess whether the program has been implemented according to plan.

c. Measuring whether the implementation of the program is in accordance with the standards.

d. Program evaluation can identify and find which dimensions of the program are working and which are not.

e. Program staff development.

f. Meet the provisions of the law.

g. Program accreditation.

h. Measuring cost effectiveness and cost-efficiency.

i. Make decisions about the program.

j. Accountability.

k. Provide feedback to program leaders and staff.

1. Develop a theory of evaluation science (Wirawan, 2018).

\subsection{Definition and Objectives of K3RS}

The definition of Occupational Health and Safety can be grouped in philosophical, scientific and legal terms (Tarwaka, 2017).

a. Philosophically. K3 can be defined as an effort to ensure the integrity and perfection of both spiritually and spiritually humans (workers) and their work in the context of a safe, just, prosperous and prosperous society.

b. Scientifically. K3 can be defined as a science and its application both technically and technologically in an effort to prevent accidents and the emergence of occupational diseases.

c. From a legal point of view. K3 is defined as an effort to protect workers and other people who are always in a healthy and safe condition at work, and production sources can be run safely, productively and efficiently.

Occupational Health is the responsibility of all of us. Safety at work is not the responsibility of company leaders or workers only, but we are all required to give a role to socialize and preserve (Sucipto, 2017). Occupational health is part of health science and its practice in curative, preventive, promotional, and rehabilitative health care so that the workforce and the community can obtain the highest degree of health to be able to work productively (Suma'mur, 2018).Hospital Occupational Health and Safety (K3RS) are all activities carried out to ensure and protect the safety and health of all human resources in hospitals and the hospital environment through an effort to prevent work accidents and the emergence of occupational diseases in hospitals. 2015).K3RS (Hospital Occupational Health and Safety) are all activities to ensure and protect the safety and health of hospital human resources, patients, patient companions, visitors, and the hospital environment through efforts to prevent occupational accidents and occupational diseases in hospitals. Ministry of Health RI, 2016).In Law no. 36 of 2009 concerning Health, in article 165 states that workplace managers are obliged to carry out all forms of health efforts through prevention, improvement, treatment and recovery efforts for workers. Hospitals must ensure the health and safety of both patients, service providers or workers and the surrounding community from various potential hazards in the hospital.

Therefore, hospitals are required to carry out Occupational Health and Safety (K3) Efforts that are carried out in an integrated and comprehensive manner so that the risk of occupational diseases (PAK) and 
occupational accidents (KAK) in hospitals can be avoided and minimized (Kemenkes RI, 2014). 2010). The basic concept of K3RS is an integrated effort of all hospital workers, patients, visitors/carriers of the sick to create a healthy, safe and comfortable work environment, hospital workplace for hospital workers, patients, visitors/accompanists for the sick as well as for the community and hospital environment.The purpose of implementing Hospital Occupational Health and Safety (K3RS) is to create Occupational Health and Safety in hospitals in an optimal, effective, efficient and sustainable manner (Kemenkes RI, 2015).

Hospital Occupational Health and Safety Program (K3RS)

Several Hospital Occupational Health and Safety (K3RS) programs that must be implemented include:

a. Development of Hospital Occupational Health and Safety (K3RS) policies;

b. Cultivating Hospital Occupational Safety and Health (K3RS) behavior;

c. HR Development for Hospital Occupational Health and Safety (K3RS);

d. Development of guidelines, technical instructions and Standard Operational Procedure (SOP) for Hospital Occupational Health and Safety (K3RS);

\section{METHODS}

The type of research used in this study is a qualitative research with an in-depth interview and observation approach design to describe how the study of planning and implementation of Occupational Safety and Health (K3RS) at Hospital Embung Fatimah Regional Batam.Informants in this study were parties who had the authority and/or knowledge regarding the planning and implementation of Hospital Occupational Safety and Health (K3RS) at the Hospital Embung Fatimah Regional, Batam as many as 8 people, namely the Director or Deputy Director of the Hospital Embung Fatimah Regional. Batam, head of K3RS, head of environmental health installations, head of medical services, head of non-medical services to find out the process of implementing K3 at Hospital Embung Fatimah Regional General Batam, 1 hospital waste manager, 1 doctor and 1 nurse.

Data collection techniques in this study are as follows: (Martha \& Kresno, 2016)

1) Observation. Observation as a data collection technique has specific characteristics when compared to other techniques, namely interviews and questionnaires. If interviews and questionnaires always communicate with people, then observation is not limited to people, but also other natural objects. Observation is a complex process, a process composed of various biological and psychological processes. Two of the most important are the processes of observation and memory. Data collection techniques with observation are used when research is related to human behavior, work processes, natural phenomena and when the respondents observed are not too large (Hadi, 2016).In this case, the researcher is a non-participant observer, that is, the researcher does not actively participate in the Embung Fatimah Batam Regional General Hospital only at the time of the study (Tanzeh, 2015). With this method, researchers can generate data on the planning and implementation of Safety and Health.

2) Interview(interview). In terms of interviews or interviews, Creswell stated that interviews in survey research were conducted by researchers by recording answers to questions given to respondents. Researchers ask questions to respondents with interview guidelines, listen for answers, observe behavior and record all responses from those surveyed (Creswell, 2016). Interviews are used as a data collection technique if the researcher wants to conduct a preliminary study to find problems that must be investigated, and also if the researcher wants to know things from more in-depth informants and the number of informants is small.

3) Documentation Method. Documentation is a written record of various activities or events in the past. Meanwhile, what is meant by the documentation method is collecting data by making or recording a report that is already available (Creswell, 2016). This method was used to collect data regarding the profile list of the Embung Fatimah Batam Regional General Hospital and data related to Hospital Occupational Safety and Health (K3RS).

\section{ANALYZE AND RESULT}

\subsection{Characteristics of Informants}

https://ijhp.net 
The initial plan of this study was that the informants in this study were 8 people, namely the Director or Deputy Director of the Embung Fatimah Regional General Hospital Batam, the head of the K3RS section, the head of the environmental health installation, the head of the medical service section, the head of the non-medical service section to find out the process of implementing K3 in Embung Fatimah Batam Regional General Hospital, 1 hospital waste manager, 1 doctor and 1 nurse. However, at the time of the research, 4 informants were willing to be interviewed, namely 1 Head of K3RS Section, 1 Hospital Waste Manager, 1 doctor, and 1 nurse. The characteristics of the informants of this research are as follows:

Table 1. Research Informants

\begin{tabular}{lllll}
\hline Description & \multicolumn{5}{l}{ Research Informants } \\
\cline { 2 - 5 } & $\mathbf{1}$ & $\mathbf{2}$ & $\mathbf{3}$ & $\mathbf{4}$ \\
\hline Initials & Mr. R & Mr, ST & Mr. SNH & Mr. KT \\
\hline Age (years) & 53 years old & 48 years old & 30 years & 32 years \\
\hline $\begin{array}{l}\text { Type } \\
\text { Sex }\end{array}$ & Man & Man & Man & Man \\
\hline Education & S-2 & PublicSKM & S-1 Profession & D-III \\
Final & Relations & & Doctor & Nursing \\
\hline Position & Head & Manager & Doctor & Coordinator \\
& Part & Waste & & catlab \\
\hline Years of service & 3 years & 5 years & 2.5 years & 3 years
\end{tabular}

Based on the research, it shows that the informants in The age of this study is between 30 years to 53 years, all of them male, educated at least D-III Nursing and the highest is S-2 Public Health. The informants' positions are Head of K3RS, Waste Management, Doctor, and Cathlab Coordinator. The tenure of the informant at the Embung Fatimah Regional General Hospital in Batam is between 2.5 years to 5 years.Informant 1 as Head of K3RS Division at Embung Fatimah Regional General Hospital Batam in charge of coordinating and supervising the implementation of the K3RS program, monitoring and evaluating the K3RS program if there are obstacles, and receiving reports or input to achieve the K3RS program success targets at the Embung Fatimah Regional General Hospital, Batam. Informant 2 plays a role in leading, organizing and controlling service activities at the Sanitation Installation; Prepare and draw up work plans and programs in accordance with the scope of their duties based on policies and directions from doctors and superiors;

Carry out service activities in the field of environmental health in accordance with the position; Carry out monitoring and control of work tasks that are their responsibility; Carry out evaluation, monitoring, and reporting, as well as carry out other tasks assigned by the Director of the hospital according to their field of duty.Informant 3 acts as a member of the K3RS program at the Embung Fatimah Regional General Hospital, Batam. Duty to provide occupational safety and health protection for medical and nonmedical officers. Meanwhile, Informant 4, a nurse, acts as the only full-time health worker in the hospital, her functions include maintaining and enhancing the quality of care services, assisting doctors in medical examinations in an approved manner, helping to determine cases of sufferers, as well as trying to follow up according to the authority given to him, assisting efforts to improve environmental and hospital health according to existing capabilities, taking part in work safety efforts, collecting data and making reports for statistics and evaluations.

\subsection{Making the Rules}

Interview results about K3RS regulatory makers at Hospital Embung Fatimah Batam Regional General Hospital, the answer was obtained as following :

Table 2. K3RS Regulation Maker at Embung Fatimah Regional General Hospital Batam

Informant Answer


Informant 1 The K3RS itself was formed by the hospital and its staff, based on the existing K3RS laws and regulations that we know. Law Number 1 of 1970 concerning Occupational Safety (State Gazette of the Republic of Indonesia of 1970 Number 1, Supplement to the State Gazette of the Republic of Indonesia Number 2918); Government Regulation Number 66 of 2014 concerning Environmental Health (State Gazette of the Republic of Indonesia of 2014 Number 184, Supplement to the State Gazette of the Republic of Indonesia Number 5570);

Informant 2 The K3RS itself was formed by the hospital and its staff, based on the existing K3RS laws and regulations that we know.

Informant 3 The K3RS itself was formed by the hospital and its staff, based on the existing K3RS laws and regulations that we know. Law Number 1 of 1970 concerning Occupational Safety (State Gazette of the Republic of Indonesia of 1970 Number 1, Supplement to the State Gazette of the Republic of Indonesia Number 2918); Government Regulation Number 66 of 2014 concerning Environmental Health (State Gazette of the Republic of Indonesia of 2014 Number 184, Supplement to the State Gazette of the Republic of Indonesia Number 5570);

Based on the table above shows the regulations regarding K3RS at the Embung Fatimah Batam Regional General Hospital according to Informant 1, Informant 2 and Informant 3 made by the Embung Fatimah Batam Regional General Hospital team and staff, based on the existing K3RS legislation, namely Law No. Law Number 1 of 1970 concerning Occupational Safety and Government Regulation Number 66 of 2014 concerning Environmental Health.

\subsection{Performance Indicators K3RS}

Based on the results of interviews with informants about the K3RS performance indicators at the Embung Fatimah Regional General Hospital, Batam, they are as follows:

Table 3. K3RS Performance Indicators at Embung Fatimah Regional General Hospital Batam

\begin{tabular}{cl} 
Informant & \multicolumn{1}{c}{ Answer } \\
\hline Informant 1 & $\begin{array}{l}\text { In my opinion, the success indicator of K3RS can be seen } \\
\text { the decrease in the number of work accidents and the reatizt } \\
\text { of infectious and non-infectious medical waste control } \\
\text { hospital. }\end{array}$ \\
\hline Informant & Answer \\
\hline Informant 2 & $\begin{array}{l}\text { In my opinion, the indicator is successful } \\
\text { carry out waste management, where possible } \\
\text { separated infectious and non-infectious so that } \\
\text { no infected and environmental sustainability } \\
\text { stay awake. }\end{array}$ \\
\hline In my opinion, K3RS success indicators can be \\
seen from the implementation of the K3RS program and \\
reduction in the number of accidents and illnesses
\end{tabular}


work.

Informant $4 \quad$ In my opinion, of course the value of our success

pay attention to the decrease in the number of work accidents

and begin to increase the discipline of all parties

related to maintaining $K 3 R S$.

Based on the table above, according to Informant 1, Informant 2 and Informant 3 that the K3RS performance indicators at the Embung Fatimah Ba Regional General HospitalTam, namely the decrease in the number of work accidents, the decrease in the number of occupational diseases and the realization of infectious and non-infectious medical waste control at the Embung Fatimah Regional General Hospital, Batam. Informant 4 added that the indicator of the success of K3RS performance is the increased discipline of all related parties to maintain K3RS.Based on the results of the study, it was shown that the K3RS planning at the Embung Fatimah Regional General Hospital Batam was carried out with the following steps: formulating K3RS policies, identifying sources of danger and potential hazards in hospitals, developing K3RS guidelines and SOPs, conducting OSH exercises and simulations, taking notes. reporting of work accidents and occupational diseases. on the other hand coordinating with the Infection Prevention and Control (PPI) team, fostering and supervising the work environment, fostering and supervising work safety equipment, making an incident reporting system and its follow-up.

Research conducted by Purba et al., (2018) at Mitra Sejati Hospital Medan that in planning for occupational safety and health, Mitra Sejati Hospital carried out a program regarding hospital safety and health guidelines. Program plans that have been implemented have already been established and have guidelines in overcoming occupational safety and health in hospitals. In planning for occupational safety and health, the hospital has made the achievement of SMK3 RS, which is to achieve the target the hospital has made a report recording each of the units in the hospital. Likewise research conducted by Firman (2016) that K3RS planning is implemented based on the readiness of existing equipment, because in the planning it is done if the equipment already exists so that the program that has been set will be carried out properly.K3RS planning is made based on K3RS risk management, laws and regulations, and various other requirements. Where this plan is inaugurated by the head or director of the hospital as the highest leader of the institution, the preparation and determination of K3RS is prepared based on the level of risk factors and with a routine review system for 1 (one) year depending on changes in facilities and infrastructure and work processes at the hospital concerned. (Ministry of Health RI, 2016).Hospital Occupational Health and Safety (K3RS) planning can refer to the Hospital Occupational Health and Safety Management System (K3RS) standards including self-assessment for K3RS and SMK3 accreditation. Hospital Occupational Safety and Health Planning (K3RS) includes: Identification of hazard sources, assessment and control of risk factors, making regulations, goals and objectives, performance indicators, and K3 programs (Widowati, 2018).

\section{CONCLUSION}

Based on the research results that have been presented in the previous chapter, it can be concluded as follows:

1. K3RS planning at Embung Fatimah Batam Regional General Hospital was carried out by compiling K3RS policies, identifying sources of hazards and potential hazards in hospitals, compiling K3RS guidelines and SOPs, conducting OSH exercises and simulations, recording reports of work accidents and occupational diseases. on the other hand coordinate with the Prevention and Control team Infection (PPI), guidance and supervision of the work environment, guidance and supervision of work safety equipment, makes an incident reporting system and its follow-up.

2. Implementation of K3RS at Embung Fatimah Regional General Hospital Batam The implementation of K3RS at Embung Fatimah Regional General Hospital Batam has been going well so far. The K3RS team continues to monitor the implementation of occupational safety and health for all employees. If a problem is found related to K3RS, it will immediately receive treatment. During the 
Covid-19 pandemic, the K3RS team tightened health protocols and made preventive efforts by vaccinating all employees with Covid-19. The hospital provides trash bins according to the type of waste, namely infectious, non-infectious waste and also provides a waste bin for used medical equipment. The infrastructure used in K3RS activities is still incomplete. Monitoring activities are carried out periodically to prevent work accidents. K3RS evaluation activities by holding monthly meetings to account for the performance of each section. Reports are made every time there is a work accident to get immediate treatment.

3. Supporting factors for the implementation of K3RS at Embung Fatimah Batam Regional General Hospital, namely the existence of good cooperation, mutual care for fellow employees and K3RS teams, support from all parties in preventing work accidents.

4. The inhibiting factor for the implementation of K3RS at the Embung Fatimah Regional General Hospital Batam is that there are still some employees who do not care about K3, some employees carry out their respective programs or are not integrated in a forum that is in accordance with existing rules and mechanisms, lack of supervision and reporting mechanisms, the absence of an evaluation analysis causes the success of the program to be immeasurable, obstacles are not overcome, and there is no development effort, overlapping work on the implementation of K3RS in certain units, and the K3RS work program has not been socialized to all members of the organization.

\section{REFERENCES}

[1] Apriliawati, KD, \& Ekawati, BK (2017). Effectiveness of Organizational Management of Hospital Occupational Health and Safety (K3RS) at Hospital X Semarang. Journal of Public Health, 5(1), 46-56.

[2] Arikhman, N. (2020). Analysis of the Application of Occupational Safety and Health in the Occupational Safety Program at the Sungai Dareh General Hospital. Journal of Medical Scientific Health, 11(2), 237-246.

[3] Arikunto, S. (2018). Educational Evaluation Basics. Jakarta: Earth Literacy.

[4] Asiah, N. (2020). Evaluation of the Implementation of Occupational Health and Safety Management System (SMK3) at the dr. Zainoel Abidin Banda Aceh. Faculty of Science and Technology Ar-Raniry State Islamic University Banda Aceh.

[5] Awuy et al. (2017). The inhibiting factors for the implementation of the OHS management system in construction projects in Manado City. Journal of Civil Statistics, 5(4), 187-194.

[6] Creswell, JW (2016). Research Design Qualitative, Quantitative, and Mixed Approach (Print 3).Yogyakarta: Student Library.

[7] Fuan, LK (2014). Analysis of Implementation of Compliance with Occupational Health and Safety Standards Based on Ministry of Health RI No. 1087/MENKES/SK/VIII/2010 at the Level II Putri Hijau Hospital, Kesdam I BB Medan. Masters in the Faculty of Public Health, University of North Sumatra.

[8] Hadi, S. (2016). Research Methodology (Print 3). Yogyakarta: Andi Press.

[9] IDIC. (2020). Standard Guidelines for Doctor Protection in the Covid-19 Era. Jakarta

[10] Executive Board of the Indonesian Doctors Association (IDI).

[11] ILO. (2018). Improving the Safety and Health of Young Workers. Jakarta:International Labor Organization.

[12] Indonesian Ministry of Health. (2007). Decree of the Minister of Health of the Republic of Indonesia number 432/MENKES/SK/IV/2007 concerning Guidelines for Occupational Health and Safety Management in Hospitals. Jakarta: Ministry of Health of the Republic of Indonesia.

[13] Indonesian Ministry of Health. (2010). Occupational Health and Safety Standards in Hospitals (K3RS). Jakarta: Ministry of Health of the Republic of Indonesia. 